\title{
Determination of Different Saccharides Concentration by Means of a Multienzymes Amperometric Biosensor
}

\author{
Marianna Portaccio and Maria Lepore \\ Dipartimento di Medicina Sperimentale, Università della Campania "Luigi Vanvitelli", Via S.M. di Costantinopoli, \\ 16-80134 Napoli, Italy
}

Correspondence should be addressed to Maria Lepore; maria.lepore@unicampania.it

Received 26 April 2017; Accepted 28 June 2017; Published 17 August 2017

Academic Editor: Maria Luz Rodríguez-Méndez

Copyright (C) 2017 Marianna Portaccio and Maria Lepore. This is an open access article distributed under the Creative Commons Attribution License, which permits unrestricted use, distribution, and reproduction in any medium, provided the original work is properly cited.

\begin{abstract}
A three-electrode amperometric biosensor for the detection of two different saccharides (lactose and glucose) in aqueous solutions is described. On the graphite working electrode, the glucose oxidase (GOD) and $\beta$-galactosidase ( $\beta$-gal) were coimmobilized by means of covalent bonding. The response of the biosensor as a function of the relative concentration of the two immobilized enzymes was investigated and the best working conditions were identified by measuring the sensitivity and the linear range response. In particular, our best lactose biosensor shows a linear range up to $0.010 \mathrm{mM}$ and a limit of detection (LOD) and a sensitivity equal to $0.001 \mathrm{mM}$ and $850 \pm 81 \mu \mathrm{A} / \mathrm{mM}$, respectively. For glucose, the values of the above-mentioned parameters are equal to $0.015 \mathrm{mM}$ for the linear range, $0.001 \mathrm{mM}$ for LOD, and $505 \pm 55 \mu \mathrm{A} / \mathrm{mM}$ for the sensitivity. The working parameters of our biosensors are significant in comparison with other biosensors developed for concentration determination of the two saccharides investigated in the present work. In particular, low (LOD) and high sensitivities are obtained for lactose and glucose. To challenge our biosensor with real samples, it was tested using fruit juices, skim milk, and whey.
\end{abstract}

\section{Introduction}

Saccharides play a relevant role in the food industry and the research for the development of reliable and low-cost biosensors is always very active [1]. Lactose and glucose are two of the most important saccharides and the determination of their concentration is very important for different reasons. In particular, lactose is a disaccharide that consists of one molecule of galactose and one of glucose bonded through a $\beta-1 \rightarrow 4$ glycosidic linkage. It is present in milk in a percentage varying from 2 to $8 \%$ (by weight) depending on different species and individuals [2]. In industry, the quantitative determination of lactose in milk and in dairy products is mandatory because lactose content is a fundamental parameter for evaluating milk quality $[3,4]$. Moreover, in the last years, the determination of this parameter in foods has acquired a significant role since many individuals manifest lactose intolerance and therefore cannot consume milk and dairy products without suffering and gastrointestinal disorders [5]. This intolerance is related to lack of the required enzyme lactase ( $\beta$-galactosidase) in the digestive system that inhibits the metabolization of lactose into galactose and glucose [6]. Then the determination of lactose concentration is important for industry and for medical applications.

As far as glucose is concerned, it is a monosaccharide and it is the simplest form of sugar that can be absorbed into the bloodstream. It is naturally present in foods such as grains, fruits, and vegetables and it is also one of the major ingredients in many sweeteners and processed foods. The control of glucose level especially in soft drinks is nowadays mandatory due to their role in caloric overconsumption and body weight gain [7].

Various methods have been used for determining the concentration of these two saccharides such as spectrophotometry $[8,9]$, polarimetry [10], high performance liquid chromatography [11], and infrared spectroscopy [12]. All the above-mentioned techniques are time-consuming, expensive, and they require sample pretreatment and considerable technical skills. Therefore, enzyme-based biosensors can offer a rapid, simple, and robust method to quantify lactose 
and glucose in food. These devices are particularly useful since they combine the high specificity of the enzymes with the versatility of the transducer. In the last years, different types of enzymatic biosensors for lactose [13-19] and glucose $[4,20-24]$ determination have been developed for application in food industry, but few of them have been reported for the determination of both sugars. One of the first similar devices used different enzymes (invertase, $\beta$-galactosidase, amyloglucosidase, mutarotase, and glucose oxidase) covalently immobilized on a cellulose membrane [25]. Lactose and glucose concentrations were also simultaneously determined by using a measuring cell containing lactose and glucose electrodes made by mixing galactosidase/glucose oxidase and glucose oxidase, respectively, with carbon paste [26]. Another biosensor sensitive to glucose and lactose was developed using coimmobilized ferrocene, glucose oxidase, $\beta$-galactosidase, and mutarotase on $\beta$-polymer. The ferrocene was entrapped in the $\beta$-cyclodextrin polymer and glucose oxidase, $\beta$-galactosidase, and mutarotase were cross-linked with the $\beta$-cyclodextrin polymer. In this case, cyclic voltammetry and amperometric measurements were employed in order to show the efficacy of electron transfer between immobilized glucose oxidase and a glassy carbon electrode via ferrocene included in the cavities of the $\beta$ cyclodextrin polymer [27]. More recently, Soldatkin et al. [28] reported the development of an array of biosensors for the simultaneous determination of four carbohydrates in solution. Several enzyme systems selective to lactose, maltose, sucrose, and glucose were immobilized on the surface of four conductometric transducers and served as biorecognition elements of the biosensor array. The main working characteristics of these devices are reported in Table 1.

In the present work, we discuss the functioning of an amperometric biosensor based on the use of $\beta$-galactosidase ( $\beta$-gal) and glucose oxidase (GOD) that has been prepared for lactose and glucose concentration determination in aqueous solution. The immobilization of enzymes on graphite electrodes has been carried out by means of covalent bonding [29]. The response of the biosensors as a function of the relative concentration of the two immobilized enzymes has been investigated and the best working conditions have been identified by measuring the linear range response and sensitivity of each prepared biosensor. The working parameters of the prepared devices have been compared with the performances of other similar biosensors reported in the literature. This comparison has confirmed the effectiveness of multienzymes biosensors for lactose and glucose concentration determination. The proposed biosensor has been tested with real samples using fruit juices, skim milk, and whey.

\section{Experimental}

2.1. Materials. In this work, glucose oxidase (GOD) (E.C. 1.1.3.4) from Aspergillus niger $\left(145 \mathrm{Umg}^{-1}\right)$ and $\beta$-galactosidase ( $\beta$-gal) (E.C. 3.2.1.23) from Aspergillus oryzae $\left(>8 \mathrm{Umg}^{-1}\right)$ were used.

Nitric acid, $\mathrm{N}, \mathrm{N}^{\prime}$-dicyclohexylcarbodiimide, hexamethylenediamine (HMDA), and glutaraldehyde (GA) were employed for the process of enzyme immobilization. In particular, HMDA and GA were used as the spacer and coupling agents, respectively, while the carbodiimide was used as the activator of the carboxylic groups produced on the graphite electrode surface.

Graphite rods (4 $\mathrm{mm}$ in diameter) were purchased from Agar Scientific (Agar Scientific Limited, 66a, Cambridge Road Stansted, Essex CM24 8DA, England). The platinum and the $\mathrm{Ag} / \mathrm{AgCl}$ electrodes were purchased from Radiometer Analytical (Radiometer Analytical SAS, Villeurbanne Cedex, Lyon, France).

In order to test the real functioning of our biosensor, we used four real samples of the food chain to compare the saccharides concentrations measured with our biosensor with those obtained by using Sigma colorimetric assay kits (Catalogue Number MAK011 for lactose determination and Product Code GAHK-20 for glucose determination). The used real samples were pineapple juice, orange juice, skim milk, and whey. The tests were performed in triplicate on opportunely diluted samples, and the results were presented as the mean and standard deviation.

All chemicals, including the enzyme, were purchased from Sigma (Sigma, Milan, Italy) and used without further purification.

2.2. Apparatus. The electrochemical cell (Figure 1(a)) was a three-electrode cell where the enzyme modified graphite electrode acted as a working electrode and the platinum electrode (type M241Pt) as a counter electrode. All measurements were carried out versus an $\mathrm{Ag} / \mathrm{AgCl}$ reference electrode (type REF321). A $+700 \mathrm{mV}$ potential drift between the electrodes was ensured by means of a low current potentiostat/galvanostat (model 2059 from Amel, Milan, Italy) interfaced to a PC through a board (PCI-6221) purchased from National Instruments Corporation (National Instruments, Austin, TX, USA). Electric current measurements were performed by means of a flow injection analysis (FIA) system, also shown in Figure 1(a). A continuous flow of carriers (the washing buffer solution: $0.1 \mathrm{M}$ sodium acetate, $\mathrm{pH}$ $5.0 ; T=25^{\circ} \mathrm{C}$ ) or of the mixture containing the substrate was injected through the electroanalytic cell under the control of an electrovalve (RS Components s.p.a., Cinisello Balsamo, Milan, Italy). The injected volume was $200 \mu \mathrm{L}$ and the electrical response, which constituted the output signal from the biosensor, was acquired using the Labview software package (National Instruments, Austin, TX, USA). The software accounted for the values of the background current, which was continuously subtracted from the subsequent value of the measurement. The electrical current was produced by the oxidation of the substrate by the immobilized enzyme according to the following reaction scheme:

$$
\begin{gathered}
\text { lactose }+\mathrm{H}_{2} \mathrm{O} \stackrel{\beta \text {-gal }}{\longrightarrow} \\
\beta \text {-D-glucose }+\beta \text {-D-galactose } \\
\beta \text {-D-glucose }+\mathrm{O}_{2} \stackrel{\text { GOD }}{\longrightarrow} \\
\text { D-glucone-1,5-lactone }+\mathrm{H}_{2} \mathrm{O}_{2}
\end{gathered}
$$


TABLE 1: Working parameters of biosensors for concentration determination of lactose and glucose. The asterisk means that the numerical values of sensitivity were evaluated from published linear calibration. n.a. stands for not available.

\begin{tabular}{|c|c|c|c|c|c|c|}
\hline $\begin{array}{l}\text { Immobilization } \\
\text { support \& method }\end{array}$ & Substrate & Linear range $(\mathrm{mM})$ & $\mathrm{LOD}(\mathrm{mM})$ & Sensitivity & Stability & References \\
\hline $\begin{array}{l}\text { Triacetyl cellulose } \\
\text { membranes }\end{array}$ & $\begin{array}{l}\text { Lactose } \\
\text { Glucose }\end{array}$ & $\begin{array}{l}\text { Up to } 180 \\
\text { Up to } 5\end{array}$ & $\begin{array}{l}\text { n.a. } \\
\text { n.a. }\end{array}$ & $\begin{array}{c}\sim 410^{-3} \mu \mathrm{A} / \mathrm{mM}^{*} \\
\text { n.a. }\end{array}$ & More than 10 days & {$[25]$} \\
\hline Carbon paste & $\begin{array}{l}\text { Lactose } \\
\text { Glucose }\end{array}$ & $\begin{array}{l}\text { Up to } 2.5 \\
\text { Up to } 2.5\end{array}$ & $\begin{array}{c}0.1 \\
0.05\end{array}$ & $\begin{array}{c}5.610^{-2} \mu \mathrm{A} / \mathrm{mM} \\
\text { n.a. }\end{array}$ & More than 10 days & {$[26]$} \\
\hline $\begin{array}{l}\beta \text {-Cyclodextrin } \\
\text { polymer }\end{array}$ & $\begin{array}{l}\text { Lactose } \\
\text { Glucose }\end{array}$ & $\begin{array}{l}\text { Up to } 4 \\
\text { n.a. }\end{array}$ & $\begin{array}{l}\text { n.a. } \\
\text { n.a. }\end{array}$ & $\begin{array}{c}\sim 410^{-1} \mu \mathrm{A} / \mathrm{mM}^{*} \\
\text { n.a }\end{array}$ & Two months & {$[27]$} \\
\hline $\begin{array}{l}\text { Conductometric } \\
\text { transducer using } \\
\text { gold electrodes }\end{array}$ & $\begin{array}{l}\text { Lactose } \\
\text { Glucose }\end{array}$ & $\begin{array}{l}\text { Up to } 1-3 \\
\text { Up to } 1-3\end{array}$ & $\begin{array}{l}0.001 \\
0.001\end{array}$ & $\begin{array}{c}\sim 12 \mu \mathrm{S} / \mathrm{mM}^{*} \\
\text { n.a. }\end{array}$ & Four months & {$[28]$} \\
\hline Graphite electrode & $\begin{array}{l}\text { Lactose } \\
\text { Glucose }\end{array}$ & $\begin{array}{l}\text { Up to } 1.010^{-2} \\
\text { Up to } 1.510^{-2}\end{array}$ & $\begin{array}{l}0.001 \\
0.001\end{array}$ & $\begin{array}{l}850 \pm 81 \mu \mathrm{A} / \mathrm{mM} \\
505 \pm 55 \mu \mathrm{A} / \mathrm{mM}\end{array}$ & Two months & Present work \\
\hline
\end{tabular}

The hydrogen peroxide from reaction (2) was oxidized at the anode and generated a current proportional to the lactose concentration:

$$
\mathrm{H}_{2} \mathrm{O}_{2} \stackrel{700 \mathrm{mV}}{\longrightarrow} \mathrm{O}_{2}+2 \mathrm{H}^{+}+2 \mathrm{e}^{-}
$$

The electric pathway in the production of the biosensor response is reported in Figure 1(b). A typical electrical response is illustrated in Figure 1(c), where it is possible to note the reproducibility of the measurements and the small "response time" of the biosensor. The $I_{\text {peak }}$ value was used as current response signal for different substrate concentrations.

2.3. Graphite Electrode Preparation. The enzyme immobilization was carried out on the electrode using a covalent bond [29]. A spacer (HMDA) was used to bind the enzyme to the functional carboxylic groups induced on the graphite electrode with nitric acid. The enzyme immobilization phase for all electrode types was preceded by a cleaning phase of the electrode surface using gamma alumina powder, after which the electrode was washed and sonicated in $5 \%(\mathrm{v} / \mathrm{v})$ ethanol aqueous solution. The carboxylic groups on the electrode were obtained by treating the graphite electrode for $24 \mathrm{~h}$ with an aqueous solution of nitric acid $(20 \% \mathrm{v} / \mathrm{v})$. At the end of the treatment, the graphite electrode was washed in deionized water. In particular, the treated electrodes were dipped for $2 \mathrm{~h}$ in a $0.1 \mathrm{M}$ sodium acetate buffer solution, $\mathrm{pH}$ 4.8 and $T=60^{\circ} \mathrm{C}$, containing $14 \mathrm{mg} / \mathrm{mL}$ of carbodiimide. At the end of this step, the graphite electrodes were dipped for $30 \mathrm{~min}$ at room temperature in an aqueous solution of HMDA $(5 \% \mathrm{v} / \mathrm{v})$ and then washed in deionized water for $1 \mathrm{~min}$. After this treatment, the electrode was dipped for $30 \mathrm{~min}$ at room temperature in a $10 \%(\mathrm{v} / \mathrm{v}) \mathrm{GA}$ aqueous solution containing different quantities of two enzymes. A large series of electrodes were prepared and tested in order to establish the relative quantities of GOD and $\beta$-gal enzymes able to give the best results in terms of sensitivity and stability. The whole process of enzyme immobilization is shown in Figure 1(d).

2.4. Electrode Stability. Electrode stability was tested daily by measuring the electrical response under standard conditions:
$0.08 \mathrm{mM}$ lactose, $\mathrm{pH} 6.5$, and $T=25^{\circ} \mathrm{C}$. After a 2-day period, during which the response decreased by $20 \%$ with respect to the first set of measurements, fairly stable conditions were obtained. All the experiments reported in the following section were carried out under similarly stable conditions. The electrodes were discarded when the daily measure values differed by $10 \%$ from the standard reference measure. When not in use, the biosensors were stored in $0.1 \mathrm{M}$ sodium phosphate buffer, $\mathrm{pH} 6.5$ at $4^{\circ} \mathrm{C}$.

2.5. Determination of Biosensor Working Parameters. As well known, the electrical response of an amperometric biosensor is well described by Michaelis-Menten equation:

$$
I_{\text {peak }, C}=\frac{I_{\text {peak, } \max } C}{K_{m, \text { el }}^{\text {app }}+C},
$$

where $I_{\text {peak,C }}$ is the peak current at the substrate concentration $C, I_{\text {peak,max }}$ is the peak current at saturating substrate conditions, and $K_{m, \mathrm{el}}^{\mathrm{app}}$ is a constant with the same meaning as the Michaelis-Menten constant $K_{m}^{\text {app }}$. The apex "app" was used to differentiate this value from that of the free enzyme. Indeed, when an enzyme is immobilized, the kinetic constant $K_{m}$ changes owing to the diffusional limitations introduced by the graft carrier. $K_{m, \text { el }}^{\text {app }}$ and $I_{\text {peak,max }}$ are known as electrokinetic parameters and can be used for quantifying the biosensor's performances. Moreover from Michaelis-Menten curve, it is possible to evaluate the linear calibration range and the sensitivity can be estimated as the slope of the calibration curve.

2.6. Treatment of the Experimental Data. Each experimental point in the figures is the average of six independent measurements performed under the same experimental conditions. The experimental error never exceeded 5\%.

\section{Results and Discussion}

The first part of the experimental work concerned the quantitative determination of the relative quantities of GOD and $\beta$-gal enzyme that enabled us to obtain the best sensitivity 


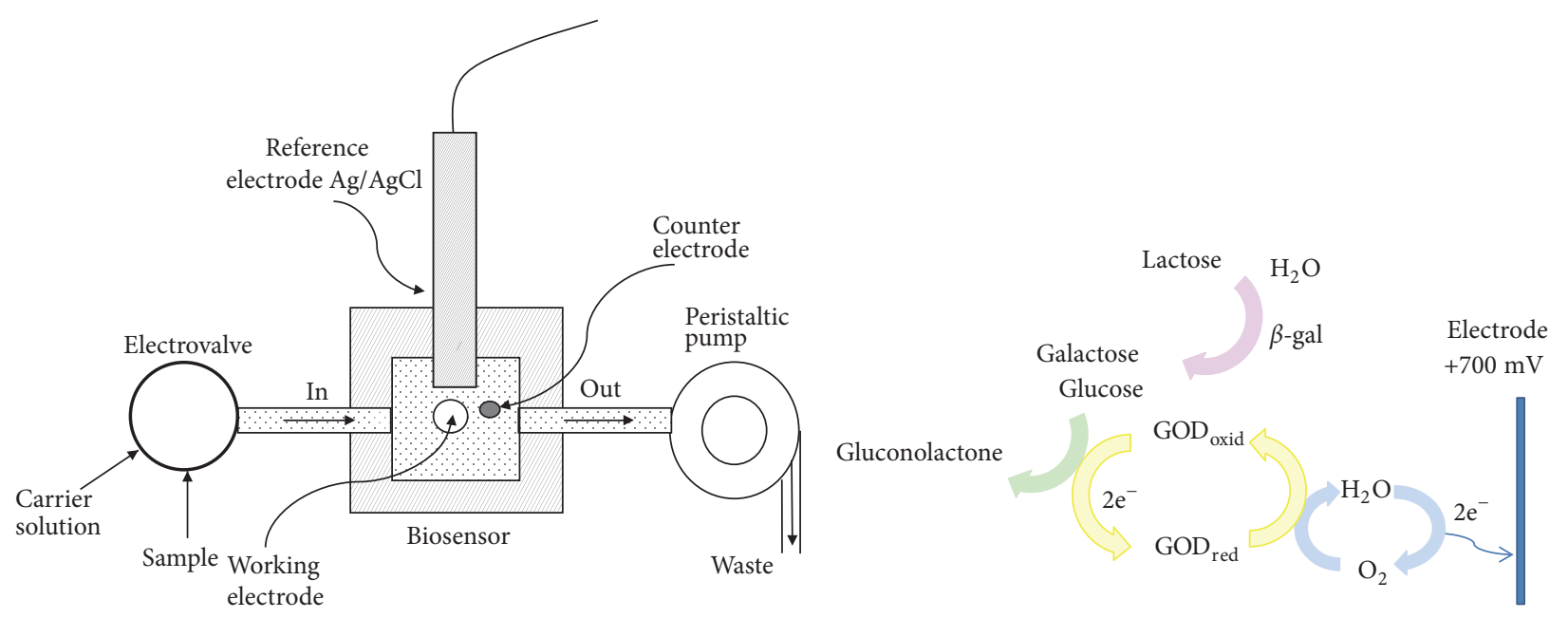

(a)

(b)

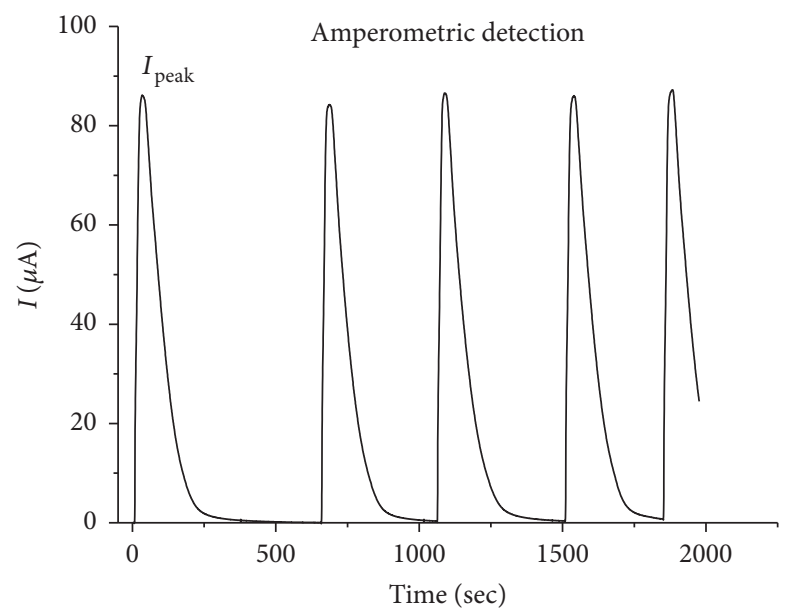

(c)<smiles>C=C1CCc2c(c(C(=O)O)c(C(=O)O)c3c(C(=O)O)c(=C)ccc23)=C1C(=O)O</smiles><smiles>CN=C=Nc1ccccc1</smiles><smiles>CC(=O)OC(=Nc1ccccc1)Nc1ccccc1</smiles><smiles>OC(=Nc1ccccc1)Nc1ccccc1</smiles>

$\mathrm{NH}_{2}-\left(\mathrm{CH}_{2}\right)_{6}-\mathrm{NH}_{2}$

Hexamethylenediamine

Graphite $-\underset{\|}{\mathrm{C}}-\mathrm{NH}-\left(\mathrm{CH}_{2}\right)_{6}-\mathrm{NH}_{2}$ $\mid \stackrel{\stackrel{\mathrm{O}}{\| \mathrm{CC}}-\left(\mathrm{CH}_{2}\right)_{3}-\stackrel{\mathrm{O}}{\mathrm{CH}}}{\text { Glutaraldehyde }}$
$\mathrm{Enz}-\mathrm{NH}_{2}$

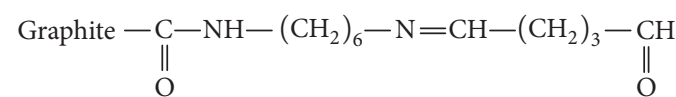

(d)

FIGURE 1: (a) Representation of the electrolytic cell and FIA system; (b) electric pathway for the production of biosensor response; (c) a typical signal obtained with a $0.5 \mathrm{mM}$ solution of lactose, at $\mathrm{pH} 6.5$ and $T=25^{\circ} \mathrm{C}$, with an electrode prepared with $\beta$-gal $=6 \mathrm{mg} / \mathrm{ml}$ and $\mathrm{GOD}=$ $2 \mathrm{mg} / \mathrm{ml}$; (d) schema of the enzyme immobilization process on graphite electrodes. 


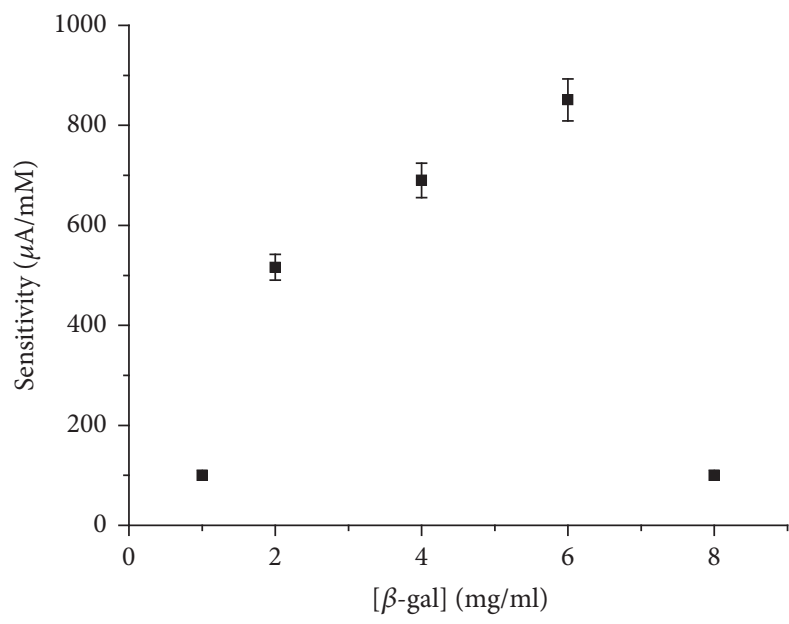

(a)

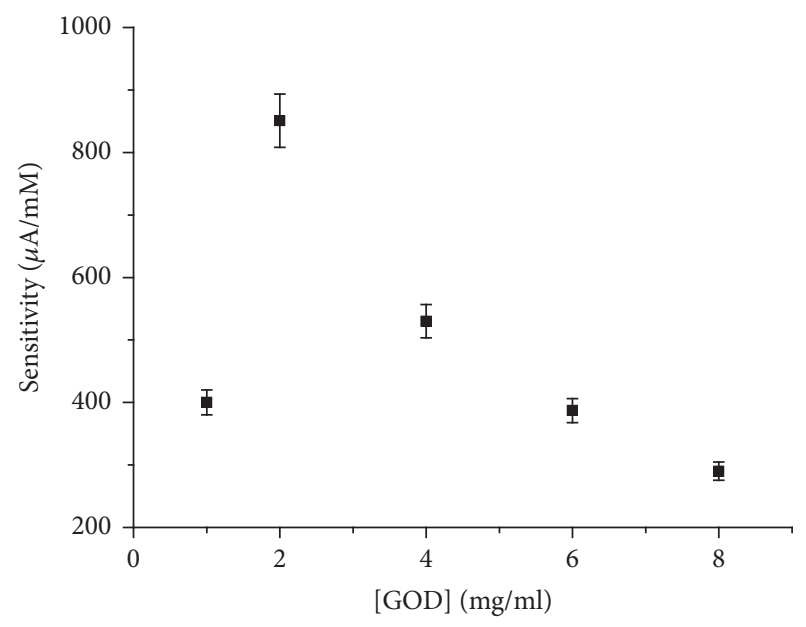

(b)

FIGURE 2: Sensitivity of different electrodes using lactose as substrate; (a) the electrodes were prepared with fixed GOD concentration $(2 \mathrm{mg} / \mathrm{ml})$ and varying $\beta$-gal concentrations; (b) the electrodes were prepared with fixed $\beta$-gal concentration $(6 \mathrm{mg} / \mathrm{ml})$ and varying GOD concentrations, [lactose] $=0.5 \mathrm{mM}$ and $\mathrm{pH}=6.5$.

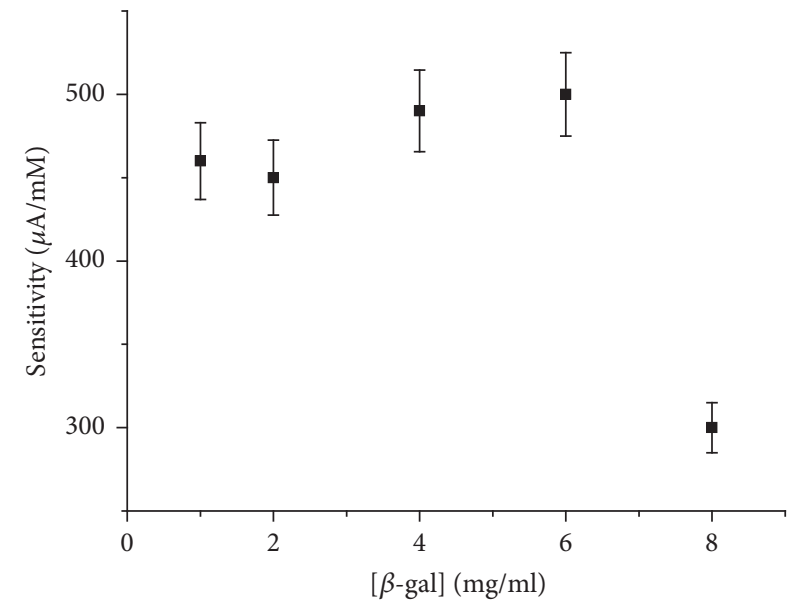

(a)

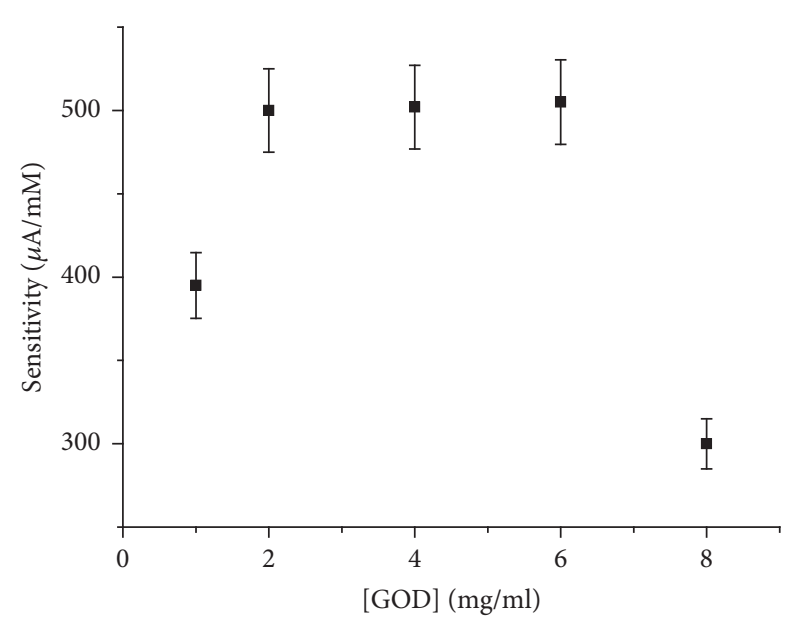

(b)

FIGURE 3: Sensitivity of different electrodes using glucose as substrate; (a) the electrodes were prepared with fixed GOD concentration $(2 \mathrm{mg} / \mathrm{ml})$ and varying $\beta$-gal concentrations; (b) the electrodes were prepared with fixed $\beta$-gal concentration (6 mg/ml) and varying GOD concentrations, [glucose] $=0.5 \mathrm{mM}$ and $\mathrm{pH}=5.5$.

and stability. For this purpose, different electrodes were prepared using different amounts of GOD and $\beta$-gal. In particular, the amounts of two enzymes varied in the range $2-8 \mathrm{mg} / \mathrm{ml}$. For each of them, the linear range calibration curves were measured and the different sensitivities were determined from their slopes. In Figures 2(a) and 2(b), the results of this series of measurements are reported using lactose as substrate. In particular, in Figure 2(a), the sensitivities for electrodes prepared with a fixed amount of GOD $(2 \mathrm{mg} / \mathrm{ml})$ and varying amounts of $\beta$-gal are reported. The values of sensitivity range in the $150-850 \mu \mathrm{A} / \mathrm{mM}$ interval and the highest sensitivity is obtained for the electrodes prepared using $2 \mathrm{mg} / \mathrm{ml}$ of GOD and $6 \mathrm{mg} / \mathrm{ml}$ of $\beta$-gal. In Figure 2(b), the sensitivities for electrodes prepared with a fixed amount of $\beta$-gal $(6 \mathrm{mg} / \mathrm{ml})$ and varying amounts of GOD are reported. In this case, the sensitivities range between 380 and $850 \mu \mathrm{A} / \mathrm{mM}$. These results show that the highest sensitivity is still obtained for the electrode prepared with $2 \mathrm{mg} / \mathrm{ml}$ of GOD and $6 \mathrm{mg} / \mathrm{ml}$ of $\beta$-gal. In Figures 3(a) and $3(\mathrm{~b})$, the results of similar measurements are reported using glucose as substrate. In this series of experiments, when electrodes were prepared using a fixed amount of GOD $(2 \mathrm{mg} / \mathrm{ml}$ ) and varying amounts of $\beta$-gal (Figure 3(a)), the sensitivities range in the $300-500 \mu \mathrm{A} / \mathrm{mM}$ interval and the highest sensitivity (460) is still obtained for the electrode prepared with $2 \mathrm{mg} / \mathrm{ml}$ of GOD and $6 \mathrm{mg} / \mathrm{ml}$ of $\beta$-gal. In Figure 3(b), sensitivities for electrodes prepared with a fixed amount of $\beta$-gal $(6 \mathrm{mg} / \mathrm{ml})$ and varying amounts of GOD are reported. In this case, the sensitivities range between 300 and $500 \mu \mathrm{A} / \mathrm{mM}$. Sensitivity values around $500 \mu \mathrm{A} / \mathrm{mM}$ are 


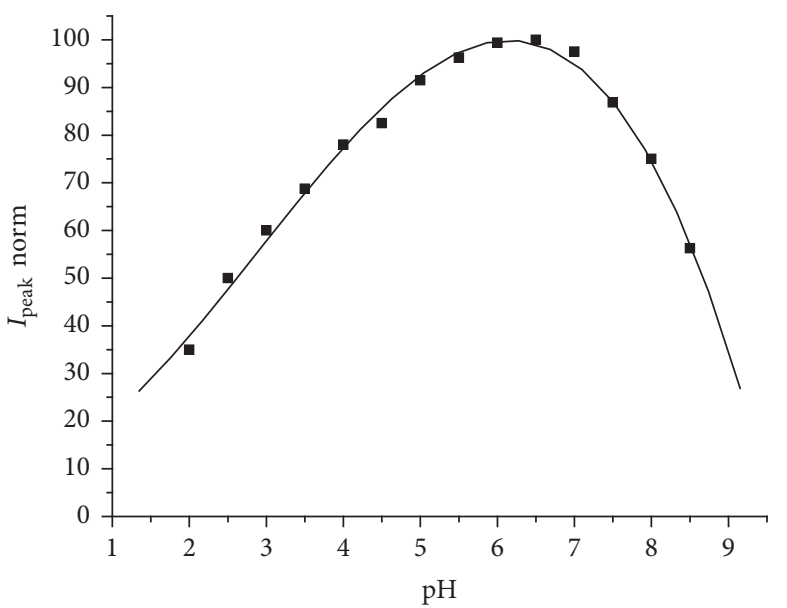

(a)

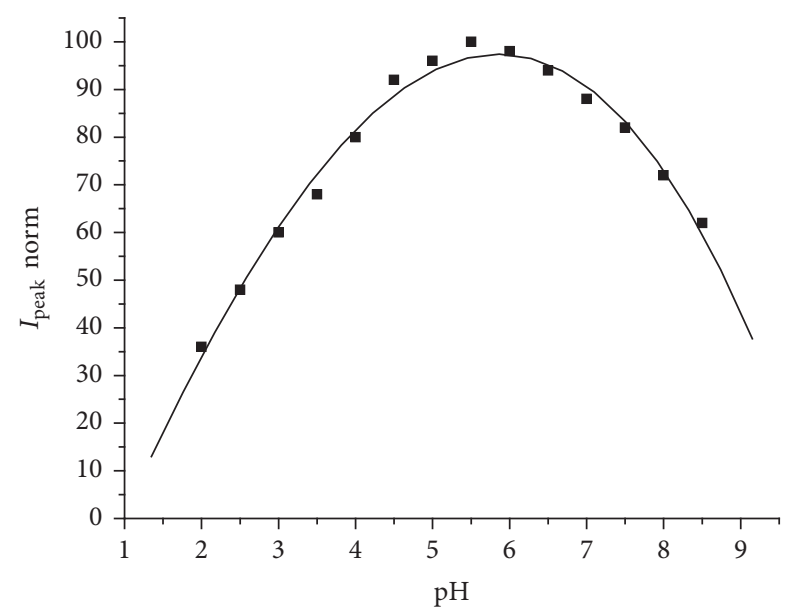

(b)

FIGURE 4: Relative $I_{\text {peak,norm }}$ values as a function of $\mathrm{pH}$ for best working electrode; (a) [lactose] $=0.5 \mathrm{mM}$ and $T=25^{\circ}$; (b) [glucose] $=0.5 \mathrm{mM}$ and $T=25^{\circ}$.

obtained for electrodes prepared with 2,4 , and $6 \mathrm{mg} / \mathrm{ml}$ of GOD and assuming a fixed $6 \mathrm{mg} / \mathrm{ml}$ of $\beta$-gal. These results confirm that the highest sensitivity for glucose is obtained for an electrode prepared with $2 \mathrm{mg} / \mathrm{ml}$ of GOD and $6 \mathrm{mg} / \mathrm{ml}$ of $\beta$-gal. Hence, the same kind of electrode that ensures the highest sensitivity for lactose, it is able to work well using glucose as substrate, even though a lower sensitivity is obtained.

After this step, the $\mathrm{pH}$ solution dependence of enzyme reaction was investigated. Since an enzyme reaction is strongly dependent on the $\mathrm{pH}$ of the solution, especially when the catalyst is immobilized [30-34], the biosensor response was studied at different values of the $\mathrm{pH}$ in the range from 3.5 to 6.5. In Figures 4(a) and 4(b), the results of this investigation are reported as the relative values of $I_{\text {peak }}$ as a function of $\mathrm{pH}$ for lactose and glucose, respectively. The glucose and lactose concentration was $0.5 \mathrm{mM}$ and the temperature $25^{\circ} \mathrm{C}$. The results in the figure clearly show that the best electrical response occurs at $\mathrm{pH} 6.5$ for lactose and at $\mathrm{pH} 5.5$ for glucose. The width of the bell-shaped response curves depends on the analyte.

Once it is established that the optimum value of the peak current for our biosensor occurs at $\mathrm{pH} 6.5$ for lactose, experiments were conducted under these conditions in order to obtain calibration curves for this saccharide. The results of the experiment are shown in Figure 5, where the peak currents are reported as a function of lactose concentration. In the (a) inset, the signal obtained for a $0.5 \mathrm{mM}$ lactose concentration is shown. The experimental data clearly indicate that the electrical response of biosensor resembles Michaelis-Menten behavior. The electrokinetic parameters $K_{m \text {,el }}^{\text {app }}$ and $I_{\text {peak,max }}$ for this biosensor are equal to $0.108 \pm 0.004 \mathrm{mM}$ and to 96.12 $\pm 1.28 \mu \mathrm{A}$, respectively. The (b) inset represents the linear range of the electrical response, that is, the calibration curve. A linear range up to $0.010 \mathrm{mM}$ is evidenced. In addition, the developed biosensor shows a sensitivity equal to $850 \pm$ $81 \mu \mathrm{A} / \mathrm{mM}$ and a limit of detection (LOD) equal to $0.001 \mathrm{mM}$. LOD is evaluated as signal-to-noise ratio equal to 3.

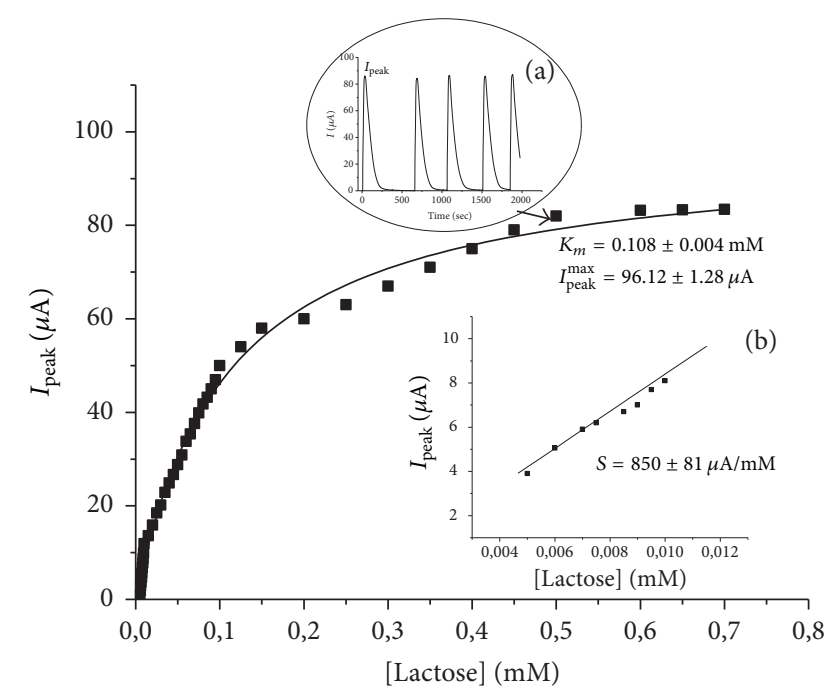

FIgURE 5: Trend of peak current value as a function of the concentration of lactose; (a) inset: biosensor response signal for a lactose concentration equal to $0.45 \mathrm{mM}$; (b) inset: linear range of the biosensor response.

In Figure 6, the peak currents are reported as a function of glucose concentration at $\mathrm{pH}$ equal to 5.5. Also in this case, the electrical response of biosensor resembles Michaelis-Menten behavior. The (a) inset shows the signal obtained for a $0.5 \mathrm{mM}$ glucose concentration. The electrokinetic parameters $K_{m, \mathrm{el}}^{\text {app }}$ and $I_{\text {peak,max }}$ for this biosensor are equal to $0.123 \pm$ $0.009 \mathrm{mM}$ and to $55.66 \pm 1.37 \mu \mathrm{A}$, respectively. A linear range up to $0.015 \mathrm{mM}$ is evidenced in the (b) inset. In addition, the developed biosensor has a sensitivity equal to $505 \pm$ $55 \mu \mathrm{A} / \mathrm{mM}$ and a LOD still equal to $0.001 \mathrm{mM}$.

The small $K_{m \text {,el }}^{\text {app }}$ values obtained for the two substrates indicate that there is a good affinity between the immobilized enzymes and the investigated saccharides and there are no significant limitations for substrate diffusion due to the immobilization process. 
TABLE 2: Comparison ofglucose or lactose concentrations in real samples as obtained using our biosensor and commercial kits.

\begin{tabular}{|c|c|c|c|c|}
\hline \multirow[b]{2}{*}{ Beverage } & \multicolumn{2}{|c|}{ Glucose (mM) } & \multicolumn{2}{|c|}{ Lactose (mM) } \\
\hline & Results with our biosensor & $\begin{array}{l}\text { Results with the } \\
\text { commercial kit }\end{array}$ & $\begin{array}{l}\text { Results with our } \\
\text { biosensor }\end{array}$ & $\begin{array}{l}\text { Results with the } \\
\text { commercial kit }\end{array}$ \\
\hline Pineapple juice & $118 \pm 19$ & $123 \pm 7$ & & \\
\hline Orange juice & $106 \pm 12$ & $110 \pm 8$ & & \\
\hline Skim milk & & & $132 \pm 15$ & $130 \pm 10$ \\
\hline Whey & & & $123 \pm 13$ & $125 \pm 8$ \\
\hline
\end{tabular}

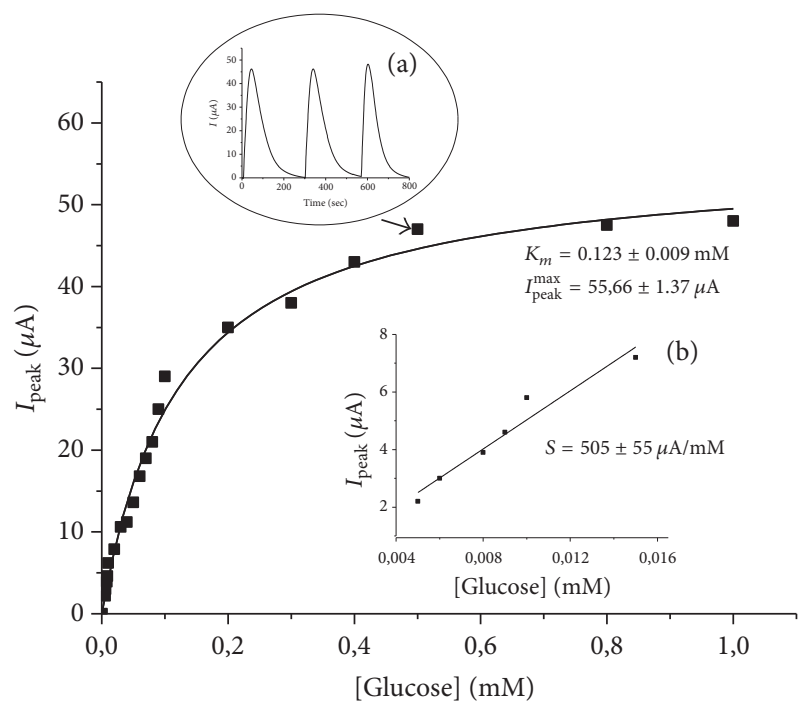

FIgURE 6: Trend of peak current value as a function of the concentration of glucose; (a) inset: biosensor response signal for a glucose concentration equal to $0.5 \mathrm{mM}$; (b) inset: linear range of the biosensor response.

All the parameters characteristic of our biosensor are reported in Table 1 together with the ones of other biosensors reported in the literature for the measurements of lactose and glucose. As can be seen, other biosensors [25-28] are characterized by a linear range larger than the one obtained by our biosensor, but its sensitivity is much higher than the others reported in the literature [25-28]. As far as LOD is concerned, it reaches very significant values for both the investigated saccharides. Also the time stability is similar to the one reported for other biosensors.

As far as real samples are concerned, the results of their measurements are reported in Table 2. As is evident, the concentrations of saccharides measured with our biosensor are in good agreement with those obtained using commercial kits. These results demonstrate that the proposed biosensor may be used in measuring glucose or lactose contents in real food samples.

\section{Conclusions}

In the present paper, the working parameters of a threeelectrode amperometric biosensor for the detection of two different saccharides (lactose and glucose) have been investigated. Two different enzymes (GOD and $\beta$-gal) were coimmobilized on the working electrode. The best working conditions have been identified by measuring the sensitivity and the linear range response. The working parameters of our biosensors are significant in comparison with the ones of other biosensors developed for concentration determination of the two saccharides investigated in the present work. In particular, low limit of detection and high sensitivities are obtained for lactose and glucose. Our biosensor has been also successfully tested with real samples using different food samples.

\section{Conflicts of Interest}

The authors declare that there are no conflicts of interest regarding the publication of this paper.

\section{References}

[1] M. S. Thakur and K. V. Ragavan, "Biosensors in food processing," Journal of Food Science and Technology, vol. 50, no. 4, pp. 625-641, 2013.

[2] L. A. Nommsen, C. A. Lovelady, M. J. Heinig, B. Lönnerdal, and K. G. Dewey, "Determinants of energy, protein, lipid, and lactose concentrations in human milk during the first $12 \mathrm{mo}$ of lactation: the darling study," American Journal of Clinical Nutrition, vol. 53, no. 2, pp. 457-465, 1991.

[3] A. Sharif, T. Ahmad, M. Q. Bilal et al., "Estimation of milk lactose and somatic cells for the diagnosis of subclinical mastitis in dairy buffaloes," International Journal of Agriculture and Biology, vol. 9, no. 2, pp. 267-270, 2007.

[4] V. Scognamiglio, F. Arduini, G. Palleschi, and G. Rea, "Biosensing technology for sustainable food safety," Trends in Analytical Chemistry, vol. 62, no. 1, pp. 1-10, 2014.

[5] P. Vernia, M. Di Camillo, and V. Marinaro, "Lactose malabsorption, irritable bowel syndrome and self-reported milk intolerance," Digestive and Liver Disease, vol. 33, no. 3, pp. 234239, 2001.

[6] D. M. Paige, T. M. Bayless, S. Huang, and R. Wexler, "Lactose intolerance and lactose hydrolyzed milk," in Physiological Effects of Food Carbohydrates, vol. 15 of ACS Symposium Series, pp. 191206, American Chemical Society, Washington, D. C., 1975.

[7] A. Lindqvist, A. Baelemans, and C. Erlanson-Albertsson, "Effects of sucrose, glucose and fructose on peripheral and central appetite signals," Regulatory Peptides, vol. 150, no. 1-3, pp. 26-32, 2008.

[8] J. S. Smith, M. C. Villalobos, and C. M. Kottemann, "Quantitative determination of sugars in various food products," Journal of Food Science, vol. 51, no. 5, pp. 1373-1375, 1986. 
[9] B. Li and Y. He, "Simultaneous determination of glucose, fructose and lactose in food samples using a continuous-flow chemiluminescence method with the aid of artificial neural networks," Luminescence, vol. 22, no. 4, pp. 317-325, 2007.

[10] R. Caprita, A. Caprita, and I. Cretescu, "Determination of Lactose Concentration in Milk Serum by Refractometry and Polarimetry," Scientific Papers: Animal Science and Biotechnologies, vol. 47, no. 1, pp. 158-216, 2014.

[11] M. T. Yang, L. P. Milligan, and G. W. Mathison, "Improved sugar separation by high-performance liquid chromatography using porous microparticle carbohydrate columns," Journal of Chromatography A, vol. 209, no. 2, pp. 316-322, 1981.

[12] D. A. Biggs, G. Johnsson, and L. O. Sjaunja, "Analysis of fat, protein, lactose and total solids by infra-red absorption," Bullettin of International Dairy Federation, vol. 208, no. 1, pp. 21-30, 1987.

[13] H. LundbäCk and B. Olsson, "Amperometric determination of galactose, lactose and dihydroxyacetone using galactose oxidase in a flow injection system with immobilized enzyme reactors and on-line dialysis," Analytical Letters, vol. 18, no. 7, pp. 871889, 1985.

[14] J. L. Garcia, A. López-Munguia, and E. Galindo, "Modeling the non-steady-state response of an enzyme electrode for lactose," Enzyme and Microbial Technology, vol. 13, no. 8, pp. 672-675, 1991.

[15] N. Adányi, E. E. Szabó, and M. Váradi, "Multi-enzyme biosensors with amperometric detection for determination of lactose in milk and dairy products," European Food Research and Technology, vol. 209, no. 3-4, pp. 220-226, 1999.

[16] T. Göktuğ, M. K. Sezgintürk, and E. Dinçkaya, "Glucose oxidase- $\beta$-galactosidase hybrid biosensor based on glassy carbon electrode modified with mercury for lactose determination," Analytica Chimica Acta, vol. 551, no. 1-2, pp. 51-56, 2005.

[17] M. Ammam and J. Fransaer, "Two-enzyme lactose biosensor based on $\beta$-galactosidase and glucose oxidase deposited by ACelectrophoresis: Characteristics and performance for lactose determination in milk," Sensors and Actuators, B: Chemical, vol. 148, no. 2, pp. 583-589, 2010.

[18] M. Yakovleva, O. Buzas, H. Matsumura et al., "A novel combined thermometric and amperometric biosensor for lactose determination based on immobilised cellobiose dehydrogenase," Biosensors and Bioelectronics, vol. 31, no. 1, pp. 251-256, 2012.

[19] F. Tasca, R. Ludwig, L. Gorton, and R. Antiochia, "Determination of lactose by a novel third generation biosensor based on a cellobiose dehydrogenase and aryl diazonium modified single wall carbon nanotubes electrode," Sensors and Actuators, B: Chemical, vol. 177, pp. 64-69, 2013.

[20] R. Monosik, M. Stredansky, J. Tkac, and E. Sturdik, "Application of enzyme biosensors in analysis of food and beverages," Food Analytical Methods, vol. 5, no. 1, pp. 40-53, 2012.

[21] T. B. Goriushkina, A. P. Soldatkin, and S. V. Dzyadevych, "Application of amperometric biosensors for analysis of ethanol, glucose, and lactate in wine," Journal of Agricultural and Food Chemistry, vol. 57, no. 15, pp. 6528-6535, 2009.

[22] Y. Song, K. Qu, C. Zhao, J. Ren, and X. Qu, "Graphene oxide: intrinsic peroxidase catalytic activity and its application to glucose detection," Advanced Materials, vol. 22, no. 19, pp. 22062210, 2010.

[23] L. G. Dias, A. M. Peres, T. P. Barcelos, J. Sá Morais, and A. A. S. C. MacHado, "Semi-quantitative and quantitative analysis of soft drinks using an electronic tongue," Sensors and Actuators, B: Chemical, vol. 154, no. 2, pp. 111-118, 2011.
[24] K. Narsaiah, S. N. Jha, R. Bhardwaj, R. Sharma, and R. Kumar, "Optical biosensors for food quality and safety assurance-A review," Journal of Food Science and Technology, vol. 49, no. 4, pp. 383-406, 2012.

[25] E. Watanabe, M. Takagi, S. Takei, M. Hoshi, and C. Shu-gui, "Development of biosensors for the simultaneous determination of sucrose and glucose, lactose and glucose, and starch and glucose," Biotechnology and Bioengineering, vol. 38, no. 1, pp. 99103, 1991.

[26] T. Katsu, X. Zhang, and G. A. Rechnitz, "Simultaneous determination of lactose and glucose in milk using two working enzyme electrodes," Talanta, vol. 41, no. 6, pp. 843-848, 1994.

[27] H. Liu, H. Li, T. Ying, K. Sun, Y. Qin, and D. Qi, “Amperometric biosensor sensitive to glucose and lactose based on coimmobilization of ferrocene, glucose oxidase, $\beta$-galactosidase and mutarotase in $\beta$-cyclodextrin polymer," Analytica Chimica Acta, vol. 358, no. 3, pp. 137-144, 1998.

[28] O. O. Soldatkin, V. M. Peshkova, O. Y. Saiapina et al., "Development of conductometric biosensor array for simultaneous determination of maltose, lactose, sucrose and glucose," Talanta, vol. 115, pp. 200-207, 2013.

[29] M. Portaccio, S. Di Martino, P. Maiuri et al., "Biosensors for phenolic compounds: the catechol as a substrate model," Journal of Molecular Catalysis B: Enzymatic, vol. 41, no. 3-4, pp. 97-102, 2006.

[30] M. Portaccio, M. El-Masry, N. Rossi Diano et al., "An amperometric sensor employing glucose oxidase immobilized on nylon membranes with different pore diameter and grafted with different monomers," Journal of Molecular Catalysis B: Enzymatic, vol. 18, no. 1-3, pp. 49-67, 2002.

[31] D. Durante, R. Casadio, L. Martelli et al., "Isothermal and nonisothermal bioreactors in the detoxification of waste waters polluted by aromatic compounds by means of immobilised laccase from Rhus vernicifera," Journal of Molecular Catalysis B: Enzymatic, vol. 27, no. 4-6, pp. 191-206, 2004.

[32] A. De Maio, M. El-Masry, S. Di Martino et al., "A Novel Packed-Bed Bioreactor Operating under Isothermal and NonIsothermal Conditions," Biotechnology and Bioengineering, vol. 86, no. 3, pp. 308-316, 2004.

[33] A. De Maio, M. M. El-Masry, M. Portaccio et al., "Influence of the spacer length on the activity of enzymes immobilised on nylon/polyGMA membranes: part 1. Isothermal conditions," Journal of Molecular Catalysis B: Enzymatic, vol. 21, no. 4-6, pp. 239-252, 2003.

[34] A. Attanasio, N. Diano, V. Grano et al., "Nonisothermal bioreactors in the treatment of vegetation waters from olive oil: laccase versus syringic acid as bioremediation model," Biotechnology Progress, vol. 21, no. 3, pp. 806-815, 2005. 


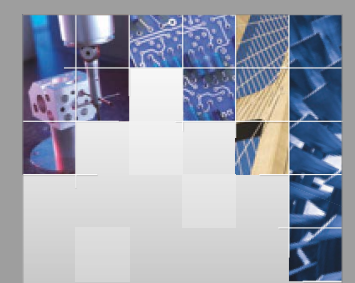

\section{Enfincering}
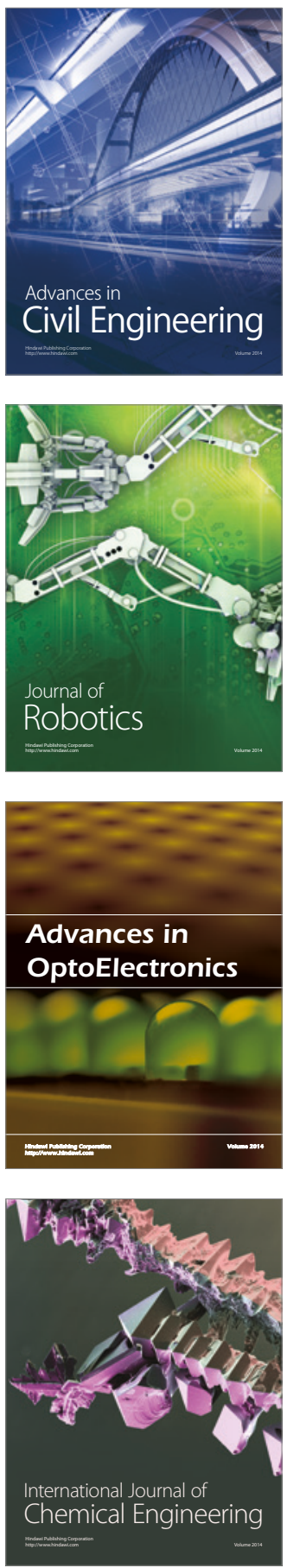

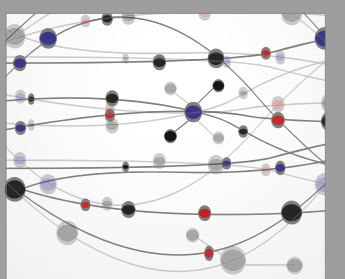

The Scientific World Journal

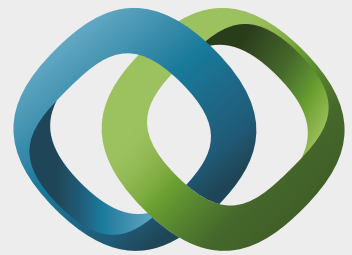

\section{Hindawi}

Submit your manuscripts at

https://www.hindawi.com
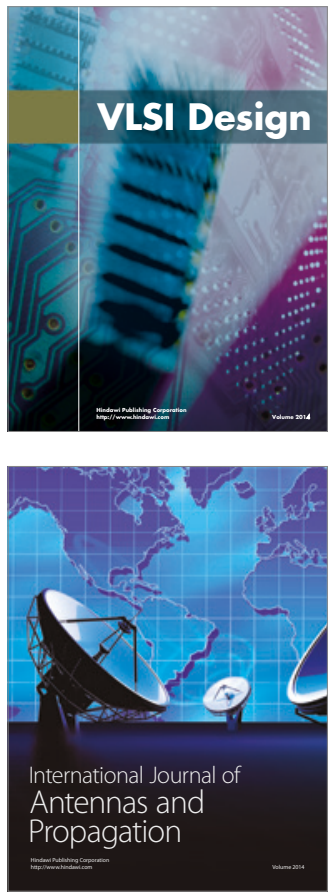

\section{Rotating}

Machinery
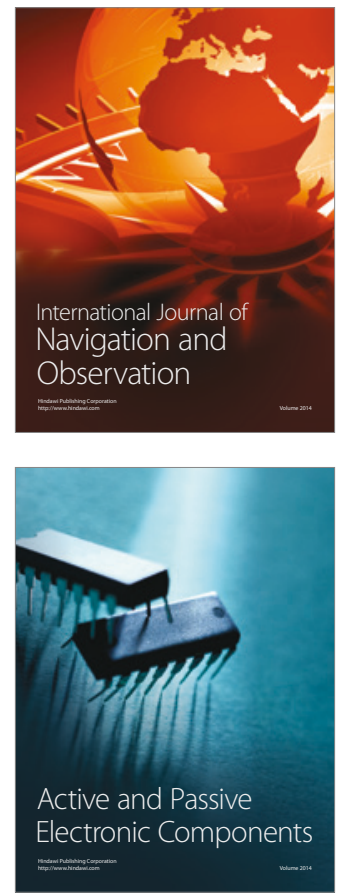
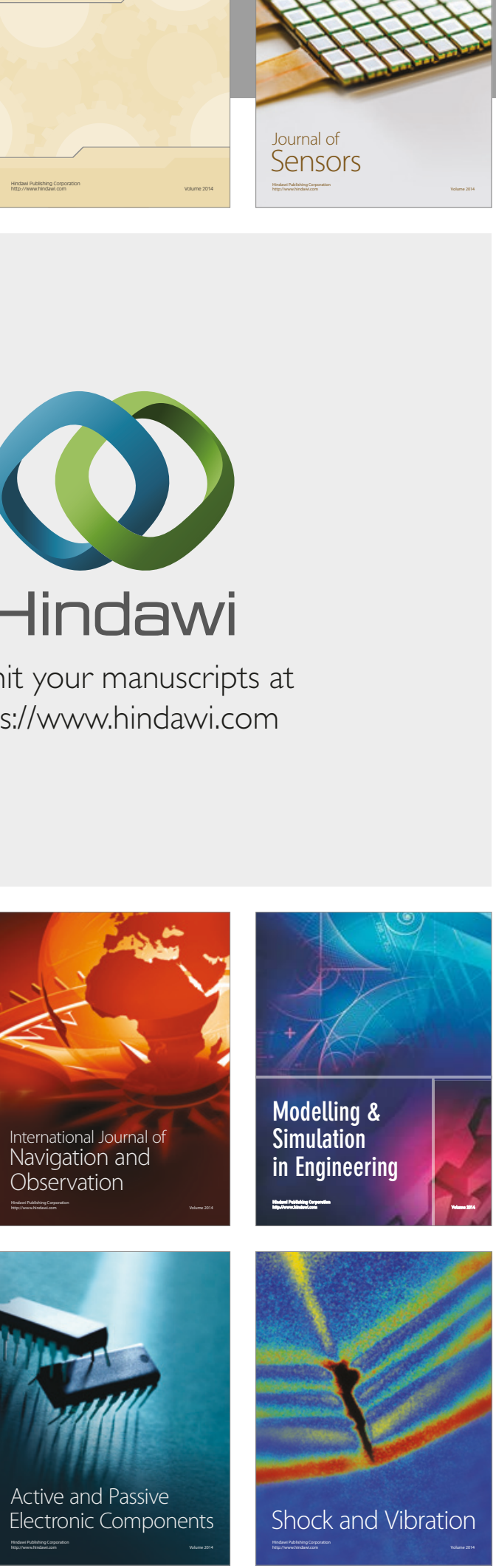
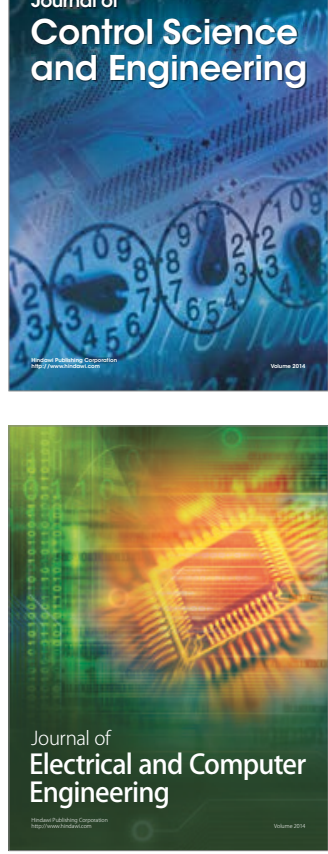

Distributed

Journal of

Control Science

and Engineering
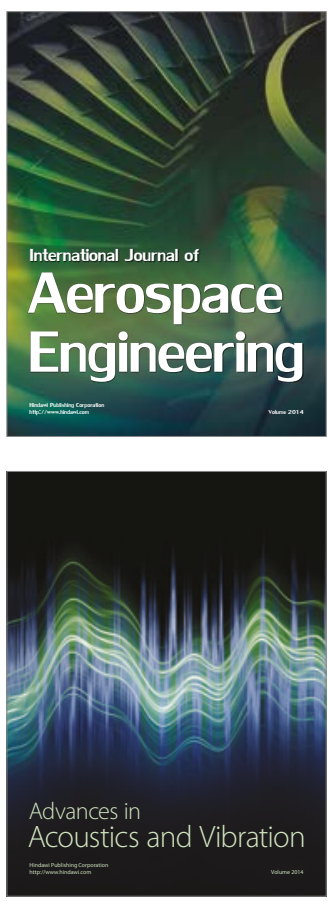

Sensor Networks 